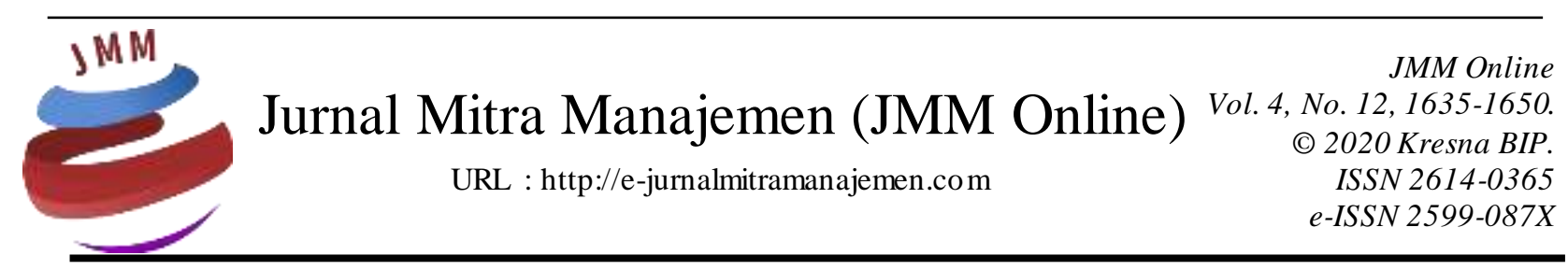

\title{
PENGARUH INTERNAL MARKETING, KOMITMEN ORGANISASIONAL, ORIENTASI PERUSAHAAN TERHADAP KINERJA KARYAWAN DI BANK CIMB NIAGA SURABAYA
}

\author{
Mira Gayatri Kartika \\ Sekolah Tinggi Ilmu Ekonomi Fatahillah
}

\section{INFORMASI ARTIKEL}

Dikirim : 17 Desember 2020

Revisi pertama : 21 Desember 2020

Diterima : 23 Desember 2020

Tersedia online : 08 Januari 2021

Kata Kunci: Internal Marketing, Komitmen Organisasional, Orientasi Perusahaan, Kinerja

Email :gayatri@stiefatahillahsby.ac.id

\section{ABSTRAK}

Penelitian ini bertujuan untuk menganalisis pengaruh internal marketing terhadap komitmen organisasional, orientasi perusahaan dan kinerja karyawan. Selain itu penelitian juga bertujuan menganalisis pengaruh dari komitmen organisasional terhadap orientasi perusahaan dan kinerja, serta menguji pengaruh orientasi perusahaan terhadap kinerja karyawan. Penelitian dilakukan di bank CIMB Niaga cabang Surabaya, dengan populasi adalah seluruh pegawai perusahaan sebanyak 480. Total ukuran sampel yang diambil sebanyak 173 pegawai dengan metode pengambilan sampel secara convenience random sampling.

Hasil pengujian membuktikan bahwa internal marketing terbukti berpengaruh signifikan terhadap komitmen organisasional pegawai bank CIMB Niaga Surabaya, dengan nilai $t$ hitung sebesar 9,232. Internal marketing juga terbukti berpengaruh signifikan terhadap orientasi pasar dengan nilai $t$ hitung sebesar 5,220,dan terhadap kinerja dengan nilai $t$ hitung sebesar 3,122. Pengujian terhadap pengaruh komitmen organisasional terhadap orientasi perusahaan di dapatkan nilai t hitung sebesar 4,290, sementara pengaruhnya terhadap kinerja karyawan didapatkan nilai $t$ hitung sebesar 4,477. Pengaruh orientasi perusahaan terhadap kinerja karyawan di dapatkan hasil t hitung sebesar 3,906. Hasil diatas menyimpulkan bahwa internal marketing berpengaruh baik secara langsung terhadap kinerja juga berpengaruh tidak langsung melalui mediasi komitmen organisasional dan orientasi perusahaan. Secara keseluruhan model internal marketing, komitmen organisasional dan orientasi perusahaan dapat menjelaskan kinerja karyawan bank CIMB Niaga mencapai 48,1 persen dengan nilai $F$ hitung sebesar 52,205 yang berarti model telah dinyatakan fit sebagai prediktorkinerja karyawan. 


\section{PENDAHULUAN \\ Latar Belakang}

Intensitas persaingan bisnis telah memaksa perusahaan mencari dan menciptakan keunggulan persaingan (competitive advantage) melalui orientasi perusahaan dengan mamaksimalkan kepuasan pelanggan (customer satisfaction). Namun demikian, di perusahaan sering menemukan hambatan dalam mengimplementasikan kebijakan orientasi perusahaan terkait kepuasan pelanggan. Dukungan internal khususnya peran karyawan non marketing masih rendah, dan menganggap bahwa tugas dari pemasaran produk dan layanan adalah bagian dari pemasaran. Kondisi ini yang kemudian mendorong Berry dkk. memperkenalkan konsep "Internal Marketing" guna menciptakan competitive advantage dalam memberikan layanan yang berkualitas.(Cahyoadi, 2016)

Campton dalam (Cahill, 2010:6) menjelaskan mengapa internal marketing dibutuhkan perusahaan untuk membuat pelanggannya senang dan terus membeli produk dan layanannya. Program aksi internal (internal action) merupakan prasarat kesuksesan bagi pemasaran eksternal. Jika pelanggan dari luar dapat merasakan layanan lebih baik sebagai hasil upaya internal marketing, maka pelanggan akan kembali untuk membeli yang perusahaan tawarkan. Konsep seperti ini berlaku bagi perusahan-perusahan penjual jasa profesional, perusahaan jasa, perusahaan manufaktur, maupun usaha non profit.(Rangkuti, 2017)

Di Indonesia kajian yang fokus terhadap internal marketing khususnya pada sektor perbankan masih jarang dilakukan. Penelitain tentang internal marketing baru dilakukan oleh Victory dan Dharmayanti (Victory, 2014) yang mengkaitkan internal marketing dengan kinerja perusahaan dan menyelediki kemampuan mediasi dari rebranding dan market orientation dengan obyek studi adalah jasa perhotelan, dan Pranowo (Toha, 2018) melakukan pengujian terhadap pengaruh internal marketing terhadap kinerja organisasi menggunakna variabel mediasi peran kompetensi organisasional di dalam perusahaan non profit .

Banyak industri perbankan dikala ini mulai terdorong buat lebih menguatkan basis strateginya dengan konsep- konsep customer focused ataupun marked oriented culture buat senantiasa bisa mengakses pasarnya secara menguntungkan serta menjamin perkembangan berkepanjangan. Tingkatkan kepentingan tentang kepuasan nasabah, pergantian teknologi yang kilat serta tantangan persaingan global menuntut efektifitas strategi pemasaran buat mempertahankan serta mengembangakan keunggulan bersaing sesuatu industri (Fatonah \& Awatara, 2019). Bagaikan industri yang mengandalkan jasa bagaikan komoditas utama, Bank wajib menyadari kalau watak jasa mengaitkan aspek keterlibatan pelanggan dalam penciptaan serta berartinya aspek waktu, dan memerlukan faktor strategis yang lain. Jasa ialah sesuatu kinerja, perbuatan ataupun proses, sehingga acapkali susah buat diidentifikasi sebab mencuat secara simultan pada dikala jasa tersebut dibeli ataupun disantap. Karena itu landasan dari pemasaran jasa terletak dari mutu layanan jasa sebab yang dipasarkan dalam bisnis ini merupakan kinerja (Fatihudin \& Firmansyah, 2019).

CIMB Niaga merupakan suatu bank yang sudah berdiri lebih dari 55 tahun. Dikala ini CIMB Niaga ialah bank terbanyak keempat di Indonesia dilihat dari sisi asset, serta diakui prestasi serta keunggulannya dibidang pelayanan nasabah serta 
pengembangan manajemen. Apalagi bank CIMB Niaga sudah menjalakan Kerjasama dengan MNC Group buat tingkatkan layanan belnja online“ Rakuten" yang pula anak industri MNC Group, serta sebagian produk yang ditawarkan antara lain pada deposito ialah: tabungan usaha, tabungan berjangka, deposito on call serta rekening giro. Sedangkan produk pinjaman meliputi pinjaman UKM, pembiayaan mikro, serta corporate card. Zona consumer banking industri menawarkan pinjaman kredit kepemilikan rumah, kredit kepemilikan kendaraan sampai kredit tanpa agunan. (Meliangan et al., 2014).

Raharjo (Abrori, 2015) dalam analisisnya terhadap kinerja CIMB Niaga merumuskan kalau kinerja profitabilitas industri hadapi penyusutan dibanding saat sebelum merger. Bersumber pada rasio ROA, kinerja keuangan bank CIBM Niaga ditinjau dari sisi profitabilitas hadapi penyusutan dibanding dengan bank Niaga serta bank Lippo tadinya. Walaupun demikian bersamaan berjalannya waktu serta keberhasilan strategi merger yang diseleksi, bank CIMB Niaga mempunyai tren profitabilitas bertambah pasca merger.

Dalam upaya tingkatkan kinerja karyawannya, dikala ini bank CIMB Niaga belum sanggup memaksimalkan implementasi internal marketing sehingga menimbulkan belum maksimalnya komitmen organisasional pegawai terhadap organisasi, kurang fokusnya orientasi industri terhadap kemauan serta kepuasan nasabah, serta capaian kinerja karyawan yang belum maksimal. Bagaikan upaya industri buat tingkatkan keuntungannya merupakan menguatkan layanan dengan tingkatkan orientasi nasabahnya dengan mengimplementasikan internal marketing dalam membina ikatan dengan pelanggan. Internal marketing tidak hanya digunakan buat tingkatkan kinerja organisasi, orientasi pasar pula bisa tingkatkan komitmen organisasional karyawan. Dengan demikian mutu pelayanan serta kepuasan serta loyalitas pelanggan bisa ditingkatkan.

\section{Rumusan Masalah}

Bersumber pada penjelasan tentang internal marketing, serta perkara bank CIMB Niaga buat tingkatkan keunggulan kompetitifnya, hingga terbuat rumusan permasalahan riset bagaikan berikut:

1. Apakah Internal marketing mempengaruhi terhadap komitmen organisasional karyawan pada Bank CIMB Niaga Surabaya?

2. Apakah Internal marketing mempengaruhi terhadap orientasi industri Bank CIMB Niaga Surabaya?

3. Apakah Internal marketing mempengaruhi terhadap kinerja karyawan Bank CIMB Niaga Surabaya?

4. Apakah Komitmen organisasional mempengaruhi terhadap orientasi industri Bank CIMB Niaga Surabaya?

5. Apakah Komitmen organisasional mempengaruhi terhadap kinerja karyawan Bank CIMB Niaga Surabaya?

6. Apakah Orientasi industri mempengaruhi terhadap kinerja karyawan Bank CIMB Niaga Surabaya? 


\section{Tujuan Penelitian} antara lain:

Bersumber pada pertanyaan- pertanyaan riset di atas hingga tujuan dari riset ini

1. Buat menganalisis pengaruh langsung Internal marketing terhadap komitmen organisasional karyawan pada Bank CIMB Niaga Surabaya

2. Buat menganalisis pengaruh langsung Internal marketing terhadap orientasi industri Bank CIMB Niaga Surabaya

3. Buat menganalisis pengaruh langsung Internal marketing terhadap kinerja karyawan Bank CIMB Niaga Surabaya

4. Buat menganalisis pengaruh langsung Komitmen organisasional terhadap orientasi industri Bank CIMB Niaga Surabaya

5. Buat menganalisis pengaruh langsung Komitmen organisasional terhadap kinerja karyawan Bank CIMB Niaga Surabaya

6. Buat menganalisis pengaruh langsung Orientasi industri mempengaruhi terhadap kinerja karyawan Bank CIMB Niaga Surabaya

\section{KAJIAN PUSTAKA}

\section{Internal Marketing}

Zeithmal\&amp; Bitner (Prastuti \& Wikaningtyas, 2018) dalam service marketing melaporkan kalau internal marketing ialah pelayanan pemasaran yang berorientasi pada kepuasan pelayanan pemasaran yang berorientasi pada kepuasan pelayanan pemasaran yang berorientasi pada kepuasan pelayanan terhadap pelanggan. Ahmed serta Rafiq (Kuswandi\&amp; Mafazi, 2018) menarangkan konsep IM sendiri bagaikan 3 fase antara lain fase tingkatkan kepuasan serta motivasi karyawan (employee motivation and satisfaction), fase orientasi pelanggan (customer orientation) serta fase ketiga bagaikan peluasan konsep pemasaran-strategi implementasi serta pergantian manajemen (broadening the internal concept-strategy implementation and change management). Ini berarti bila terbuat sintesa dari konsep IM tersebut ada poin inti yang menarangkan apa IM tersebut. Awal: IM bagaikan kepuasan serta motivasi karyawan; kedua: IM bagaikan kepuasan pelanggan serta orientasi pelanggan; ketiga: integrasi serta koordinnasi inter- fungsional; keempat: pemasaran dengan pendekatan- pendakatan pada poin satu sampai 3; serta kelima: pelaksanaan dalam ranah kerjasama tertentu serta fungsional strategis.

\section{Komitmen Organisasional}

Setidaknya ada tiga tema utama dalam definisi tersebut, yaitu keterikatan afektif (affective attachment), persepsi biaya (perceived costs), dan kewajiban (obligation). Komitmen organisasional di definisikan sebagai kekuatan identifikasi individu terhadap organisasi untuk melibatkan dan mengkaitkan dirinya baik secara afektif, wujud dari sebuah kewajiban (obligation) maupun kesediaan untuk berkorban dalam bentuk biaya (cost).(Muslim, 2019)

Komitmen juga diartikan beberapa peneliti lain sebagai persepsi biaya, yaitu kelanjutan dari tindakan untuk tetap bertahan di organisasi, karena jika keluar dari organisasi seseorang akan mendapatkan beban biaya sebagai konsekuensi. (Mawei, 2016) 
Komitmen sebagai kewajiban (obligation. Komitmen juga diartikan "lifetime commitment" sebagai "kesadaran moral untuk tetap bertahan di perusahaan, walaupun di perusahaan tidak terdapat peningkatan status maupun kepuasan dari tahun ke tahun". Secara aktual komitmen merupakan internalisasi tekanan norma yang lebih bersifat personal.(Muis et al., 2018)

\section{Orientasi Perusahaan terhadap Pasar}

Market Orientation merupakan salah satu penelitian dalam strategi marketing yang telah dikembangkan selama 10 tahun. Market Orientation memiliki berbagai macam variasi definisi. Narver dan Slater dalam (Ginting \& Hati, 2020), mendefinisikan Market Orientation sebagai budaya perusahaan yang secara efektif dan efisien menciptakan perilaku yang penting dalam pembuatan superior value bagi pelanggan dan berlanjut pada performa bisnis. Berdasarkan definisi inilah ukuran market orientation dibagi menjadi tiga elemen, yaitu :

\section{Customer Orientation}

Orientasi pelanggan diartikan sebagai pemahaman yang memadai tentang kebutuhan dan keinginan serta target beli pelanggan pada masa kini maupun masa yang akan datang dengan tujuan agar dapat menciptakan nilai unggul bagi pembeli secara terus menerus

\section{Competitor Orientation}

Orientasi pesaing berarti bahwa perusahaan yang berorientasi pada pesaing sering dilihat sebagai perusahaan yang mempunyai strategi yang ditarik berdasarkan informasi mengenai pesaing. Bagaimana merespon tindakan pesaing dan juga bagaimana manajemen puncak didalam mendiskusikan strategi pesaing Narver dan Slater dalam (Ginting \& Hati, 2020)

\section{Interfunctional Coordination}

Narver dan Slater dalam (Ginting \& Hati, 2020) menyatakan bahwa koordinasi interfungsional merupakan kegunaan dari sumber daya perusahaan yang terkoordinasi dalam menciptakan nilai unggul bagi pelanggan yang ditargetkan. Koordinasi interfungsional menunjuk pada aspek khusus dari struktur organisasi yang mempermudah komunikasi antar fungsi organisasi yang berbeda. Koordinasi interfungsional didasarkan pada informasi pelanggan dan pesaing serta terdiri dari upaya penyelarasan bisnis, secara tipikal melibatkan lebih dari departemen pemasaran, untuk menciptakan nilai unggul bagi pelanggan.

\section{Kinerja}

Kinerja didefinisikan sebagai catatan tentang hasil-hasil yang diperoleh dari fungsi-fungsi pekerjaan tertentu atau kegiatan selama kurun waktu tertentu. Kinerja adalah keberhasilan dalam mewujudkan sasaran-sasaran strategik perusahaan dan sasaran strategik perusahaan ini merupakan hasil penerjemahan misi, visi, keyakinan dasar, nilai dasar, dan strategi perusahaan (Utomo et al., 2018). Keberhasilan strategik yang dicapai organisasi atau perusahaan perlu diukur, oleh sebab itu sasaran strategik yang menjadi basis pengukuran kinerja perlu di tentukan ukurannya dan ditentukan inisiatif strategik untuk mewujudkanya. 
Jadi penilaian kinerja sebagai penentu secara periodik efektivitas operasional suatu organisasi, bagian organisasi, dan karyawan berdasarkan sasaran, standar dan kriteria yang telah ditetapkan sebelumnya. Dengan demikian, maka diperlukanya penilaian kinerja yang menjadi landasan untuk mendesain sistem penghargaan, agar personel menghasilkan kinerjanya yang sejalan dengan kinerja yang diharapkan oleh organisasi atau perusahaan.

\section{METODE PENELITIAN}

\section{Populasi dan Sampling}

1. Populasi

Populasi merupakan kumpulan dari keseluruhan pengukuran, obyek atau individu yang sedang dikaji. Statistik tidak membatasi populasi pada sekelompok/kumpulan orang-orang, namun juga bisa mengacu pada seluruh ukuran, hitungan, atau kualitas yang menjadi fokus perhatian suatu kajian. Suatu pengamatan terhadap seluruh anggota populasi disebut sensus (Harinaldi, 2005:2). Populasi penelitian ini adalah seluruh karyawan yang ada di Bank CIMB Niaga baik di kantor cabang, maupun pada kantor cabang pembantu di seluruh wilayah Surabaya. Total populasi karyawan pada bank CIMB Niaga Surabaya mencapai 480 orang.

2. Sampel

Sampel adalah bagian, atau subset (himpunan bagian) dari suatu populasi. Populasi dapat berisi data dengan jumlah yang besar sehingga akan mengakibatkan kesulitan untuk melakukan kajian terhadap seluruh populasi, oleh sebab itu penelitian dapat dilakukan pada sampelnya saja (Harinaldi, 2005:2).

Metode penentuan ukuran sampel menggunakan perhitungan Isaac dan Michael dan disajikan dalam tabel 1 Pada jumlah populasi (N) sebesar 480 dengan toleransi kesalahan (s) sebesar 0,1 di dapatkan jumlah ukuran sampel sebanyak 173 orang. Metode pengamblan secara convenience random sampling.

Tabel 1. Tabulasi Penentuan Jumlah Sampel berdasarkan Jumlah Populasi Menggunakan Metode Isaac dan Michael

\begin{tabular}{|l|l|l|l|}
\hline \multirow{2}{*}{$\mathrm{N}$} & \multicolumn{3}{|c|}{$\mathrm{s}$} \\
\cline { 2 - 4 } & \multicolumn{1}{|c|}{$1 \%$} & \multicolumn{1}{|c|}{$5 \%$} & $10 \%$ \\
\hline 10 & 10 & 10 & 10 \\
25 & 24 & 23 & 23 \\
50 & 47 & 44 & 42 \\
100 & 87 & 78 & 73 \\
150 & 122 & 105 & 97 \\
200 & 154 & 127 & 115 \\
300 & 207 & 161 & 147 \\
400 & 250 & 186 & 162 \\
460 & 272 & 198 & 171 \\
$\underline{480}$ & 279 & 202 & $\underline{\underline{173}}$ \\
500 & 285 & 205 & 176 \\
1000 & 399 & 258 & 213 \\
\hline
\end{tabular}

Sumber: Sugiyono (2013:126) 


\section{Metode Pengumpulan Data Penelitian}

1. Kuisioner

Metode pengumpulan data dalam penelitian ini antara lain:

Metode ini merupakan metode pengumpulan data dengan memberikan pernyataan-pernyataan tertulis kepada responden yang secara logis berhubungan dengan masalah penelitian.

\section{Dokumentasi}

Metode ini dilakukan dengan cara memperoleh informasi dari buku-buku, referensi, mencari informasi langsung pada internet serta majalah, surat kabar yang berhubungan dengan penelitian ini.

\section{Teknik Analisis Data}

Teknik analisis yang digunakan dalam penelitian ini adalah teknik analisis regresi linear berganda, dengan bantuan program Computer Statistical Package for Social Science (SPSS) 19 for windows. Analisa ini digunakan untuk mengetahui atau mengukur pengaruh antara variabel bebas dengan variabel terikat yang dinyatakan dalam bentuk persamaan matematik. Adapun bentuk umum dari persamaan regresi linear berganda secara sistematis adalah sebagai berikut :

Ada tiga persamaan yang dianalisis dan diuji dalam penelitian ini:

$$
\begin{aligned}
& \mathrm{X} 2=\beta_{0}+\beta_{1} \mathrm{X}_{1}+\mathrm{e} \\
& X 3=\beta_{0}+\beta_{2} X_{1}+\beta_{3} X_{2}+e \\
& Y=\beta_{0}+\beta_{4} X_{1}+\beta_{5} X_{2}+\beta_{6} X_{3}+e \\
& \text { Dimana : } \\
& \mathrm{Y} \quad=\text { Kinerja karyawan } \\
& \mathrm{X}_{1} \quad=\text { Internal Marketing } \\
& \mathrm{X}_{2} \quad=\text { Komitmen organisasional } \\
& \mathrm{X}_{3} \quad=\text { Orientasi perusahaan } \\
& \beta_{0} \quad=\text { Konstanta } \\
& \beta_{1, \ldots, \beta_{6}}=\text { Koefisien variabel bebas } \\
& \mathrm{e}=\text { Estimate of error }
\end{aligned}
$$

\section{HASIL PENELITIAN DAN PEMBAHASAN \\ Analisis Regresi Linier Berganda}

Penelitian ini menggunakan dua model persamaan untuk menjelaskan dan membuktikan hipotesis penelitian. Persamaan pertama adalah menjelaskan pengaruh variabel internal marketing, komitment organisasional dan orientasi perusahaan terhadap kinerja karyawan pada bank CIMB Niaga cabang Surabaya. Berdasarkan hubungan antara variabel yang dirumuskan dalam rumusan masalah, tujuan maupun hipotesis maka model persamaan penelitian dibedakan menjadi 3 model persamaan. Hasil analisis data selanjutnya ringkasannya disajikan dalam Tabel 2 yang menyajikan dua model persamaan penelitian. 
Tabel 2. Model Koefisien Regresi Linier Berganda

\begin{tabular}{|c|c|c|c|c|c|}
\hline Persamaan & Fungsi & $\mathrm{b}$ & t hitung & sig. & Hipotesis \\
\hline \multirow[t]{2}{*}{ I } & Konstanta & 1,181 & 4,857 & 0,000 & $\begin{array}{l}\text { H0 } \\
\text { ditolak }\end{array}$ \\
\hline & Internal Marketing (x1) & 0,639 & 9,232 & 0,000 & $\begin{array}{l}\text { H0 } \\
\text { ditolak }\end{array}$ \\
\hline \multirow{4}{*}{ II } & & & & & $\mathrm{H} 0$ \\
\hline & Konstanta & 0,802 & 3,113 & 0,002 & $\begin{array}{l}\text { ditolak } \\
\text { H0 }\end{array}$ \\
\hline & $\begin{array}{l}\text { Internal Marketing }(x 1) \\
\text { Komitmen }\end{array}$ & 0,439 & 5,220 & 0,000 & $\begin{array}{l}\text { ditolak } \\
\text { H0 }\end{array}$ \\
\hline & Organisasional (X2) & 0,326 & 4,290 & 0,000 & ditolak \\
\hline \multirow[t]{4}{*}{ III } & Konstanta & 0,557 & 2,231 & 0,027 & $\begin{array}{l}\text { H0 } \\
\text { ditolak } \\
\text { H0 }\end{array}$ \\
\hline & $\begin{array}{l}\text { Internal Marketing }(x 1) \\
\text { Komitmen }\end{array}$ & 0,267 & 3,122 & 0,002 & $\begin{array}{l}\text { ditolak } \\
\text { H0 }\end{array}$ \\
\hline & Organisasional (X2) & 0,337 & 4,477 & 0,000 & ditolak \\
\hline & $\begin{array}{l}\text { Orientasi Perusahaan } \\
(\mathrm{X} 3)\end{array}$ & 0,282 & 3,906 & 0,000 & $\begin{array}{l}\text { H0 } \\
\text { ditolak }\end{array}$ \\
\hline
\end{tabular}

Keterangan: Persamaan I, variabel terikat : Komitmen organisasional (x2)

Persamaan II, variabel terikat : Orientasi Perusahaan (x3)

Persamaan III, variabel terikat : Kinerja karyawan (Y)

Sebagaimana disajikan dalam ringkasan hasil analisis regresi linier berganda pada Tabel 2, model regresi linier penelitian ini dapat digambarkan dalam persamaan berikut:

Persamaan I : Fungsi prediktor terhadap komitmen organisasional.

Hasil analisis data dengan menggunakan perangkat lunak statistik SPSS ver 15 terhadap data yang di dapatkan dan sebagaimana disajikan dalam Tabel 5.6 maka model persamaan fungsi prediktor terhadap komitmen organisasional (Y) dapat dinyatakan dalam persamaan berikut:

$$
\mathrm{X} 2=1,181+0,639 \mathrm{X} 1+\mathrm{e}
$$

Model persamaan diatas menunjukkan besaran nilai konstanta dari pengaruh internal marketing terhadap komitmen organisasional adalah sebesar 1,181. Nilai konstanta tersebut menggambarkan besaran tingkat komitmen organisasional pegawai ketika internal marketing dianggap dipersepsikan nol.

Pengaruh internal marketing terhadap komitmen organisasional pegawai bank CIMB Niaga ditunjukkan dengan nilai koefisien fungsi regresi sebesar 0,639 , ini berarti bahwa internal marketing mempunyai dampak positif terhadap peningkatan komitmen pegawai terhadap organisasi bank tempat bekerja. Setiap kenaikan internal marketing tiap satuannya akan dapat mengakibatkan peningkatan komitmen organisasonal pegawai sebesar 0,639 tiap satu satuan pengukurannya, sebaliknya 
terjadinya penurunan pada variabel internal marketing akan dapat mengakibatkan penurunan komitmen pegawai terhadap organisasi tempatnya bekerja.

Persamaan II : Fungsi prediktor terhadap orientasi perusahaan.

Sebagaimana disajikan dalam Tabel 2 persamaan kedua penelitiannya ini yang menjelaskan hubungan kausalitas antara internal marketing dan komitmen organisasional terhadap orientasi perusahaan:

$$
\mathrm{X} 3=0,802+0,439 \mathrm{X} 1+0,326 \mathrm{X} 2+\mathrm{e}
$$

Pada model persamaan diatas, besaran nilai konstanta diketahui sebesar 0,802 . Ini berarti ketika variabel bebas dalam model persamaan tersebut dinyatakan sebagai nol maka besaran tingkat orientasi perusahaan diperkirakan mencapai 0,802 .

Koefisien internal marketing yang menunjukkan pengaruh variabel tersebut terhadap oreintasi perusahaan bank CIMB Niaga ditunjukkan dengan nilai koefisien fungsi regresi sebesar 0,439. Koefisien tersebut menunjukkan kecendrungan pengaruh antara internal marketing terhadap orientasi perusahaan bersifat searah atau postif. Perubahan yang terjadi pada variabel internal marketing dalam bentuk kenaikan untuk tiap satuannya dapat menyebabkan kenaikan pada nilai orientasi perusahaan sebesar 0,439, sebaliknya ketika terjadi penurunan pada variabel bebas tersebut dapat mengakibatkan penurunan pada orientasi perusahan ke nasabahnya sebesar nilai koefisien tersebut.

Koefisien kedua dalam persamaan adalah pengaruh besaran pengaruh komitmen organisasional terhadap oreintasi perusahaan bank CIMB Niaga, yang ditunjukkan dengan nilai koefisien fungsi regresi sebesar 0,326. Ini berarti bahwa ada hubungan kausalitas yang bersifat positif atau searah antara komitmen organisasional terhadap orientasi pasar perusahaan. Semakin tinggi komitmen organisasional pegawai pada bank CIMB Niaga, maka akan menyebabkan kenaikan nilai orientasi perusahaan dalam pelayanan ke nasabahnya, sebaliknya terjadi penurunan pada variabel komitmen akan berdampak juga pada penurunan orientasi perusahaan.

Persamaan III : Fungsi prediktor terhadap kinerja karyawan.

Sebagaimana disajikan dalam Tabel 2 persamaan kedua penelitiannya ini yang menjelaskan hubungan kausalitas antara internal marketing, komitmen organisasional dan orientasi perusahaan terhadap kinerja karyawan, maka model persamaan regresi pada fungsi tersebut dapat dinyatakan sebagai berikut:

$$
\mathrm{Y}=0,557+0,267 \mathrm{X} 1+0,337 \mathrm{X} 2+0,282 \mathrm{X} 3+\mathrm{e}
$$

Pada model persamaan diatas, besaran nilai konstanta untuk fungsi prediktor kinerja karyawan diketahui sebesar 0,557. Ini berarti ketika variabel bebas dalam model persamaan tersebut dinyatakan sebagai nol maka besaran tingkat orientasi perusahaan diperkirakan mencapai 0,557.

Koefisien internal marketing yang menunjukkan pengaruh variabel tersebut terhadap kinerja karyawan bank CIMB Niaga ditunjukkan dengan nilai koefisien fungsi regresi sebesar 0,267. Koefisien tersebut menunjukkan kecendrungan pengaruh antara internal marketing terhadap kinerja karyawan bank CIMB Niaga bersifat searah atau postif. Ini berarti kenaikan kebijakan internal marketing dalam tiap skala 1 satuan akan berimplikasi pada kenaikan kinerja karyawan bank CIMB Niaga sebesar 0,267, 
begitu juga sebaliknya ketika terjadi penurunan pada kebijakan internal marketing akan menyebabkan penurunan kinerja karyawan sebesar nilai koefisien tersebut.

Koefisien untuk variabel komitmen organisasional yang menunjukkan pengaruh variabel tersebut terhadap kinerja karyawan bank CIMB Niaga ditunjukkan dengan nilai koefisien fungsi regresi sebesar 0,337. Angka koefisien tersebut mencerminkan kecendrungan pengaruh antara komitmen organisasional karyawan terhadap kinerja karyawan bank CIMB Niaga yang bersifat searah atau postif. Ini berarti setiap kenaikan kebijakan komitment organisasional pegawai dalam tiap satu satuannya akan berdampak pada kenaikan kinerja karyawan bank CIMB Niaga sebesar 0,337, begitu juga sebaliknya ketika terjadi penurunan pada kebijakan komitmen organisasional pegawai akan menyebabkan penurunan kinerja karyawan sebesar nilai koefisien tersebut.

Koefisien untuk variabel orientasi pasar yang menunjukkan pengaruh variabel tersebut terhadap kinerja karyawan bank CIMB Niaga ditunjukkan dengan nilai koefisien fungsi regresi sebesar 0,282. Angka koefisien tersebut mencerminkan kecendrungan pengaruh antara orientasi perusahaan terhadap kinerja karyawan bank CIMB Niaga yang bersifat searah atau postif. Ini berarti setiap kenaikan kebijakan orientasi perusahaan dalam tiap satu satuannya akan dikuti perubahan dalam bentuk kenaikan pada kinerja karyawan bank CIMB Niaga sebesar 0,282, begitu juga sebaliknya ketika terjadi penurunan pada kebijakan orientasi perusahaan akan menyebabkan penurunan kinerja karyawan sebesar nilai koefisien tersebut.

\section{Uji Hipotesis Penelitian}

Hipotesis dalam penelitian ini terdiri 6 dugaan penelitian. Pengujian menggunakan uji thitung dengan ketentuan:

1. Derajat kepercayaan ditentukan sebesar 95\% dan toleransi kesalahan 5\%, dengan demikian batas kritis $\mathrm{t}$ tabel diketahui 1,974 (Dihitung dengan furmula excel ' $=\operatorname{TINV}(0,05 ; 169)$ ' dimana 169 adalah df-n-k)

2. Formula hipotesis dapat dinyatakan sebagai berikut:

$\mathrm{HO}: \beta_{\mathrm{i}}=0$ Variabel Bebas ke-i berpengaruh signifikan terhadap variabel terikat.

$\mathrm{HO}: \beta_{\mathrm{i}}=0$ Variabel Bebas ke-i tidak berpengaruh signifikan terhadap variabel terikat.

Keteentuan penerimaan dan penolakan $\mathrm{H} 0$ :

H0 ditolak jika thitung $\geq \mathrm{t}$ tabel atau Sig. $\leq$ alpha $(0,05)$

$\mathrm{H} 0$ diterima jika thitung $<\mathrm{t}$ tabel atau sig. $>$ alpha $(0,05)$

Tabel 3. Hasil Uji Hipotesis Penelitian

\begin{tabular}{|c|c|c|c|c|c|}
\hline Hipotesis ke- & Jalur pengaruh & T hitung & Sig. & H0 & Hasil hipotesis \\
\hline 1 & $\mathrm{X} 1 \rightarrow \mathrm{X} 2$ & 9,232 & 0,000 & H0 ditolak & Terbukti \\
\hline 2 & $\mathrm{X} 1 \rightarrow \mathrm{X} 3$ & 5,220 & 0,000 & H0 ditolak & Terbukti \\
\hline 3 & $\mathrm{X} 1 \rightarrow \mathrm{Y}$ & 3,122 & 0,000 & H0 ditolak & Terbukti \\
\hline 4 & $\mathrm{X} 2 \rightarrow \mathrm{X} 3$ & 4,290 & 0,000 & H0 ditolak & Terbukti \\
\hline 5 & $\mathrm{X} 2 \rightarrow \mathrm{Y}$ & 4,477 & 0,000 & H0 ditolak & Terbukti \\
\hline 6 & $\mathrm{X} 3 \rightarrow \mathrm{Y}$ & 3,906 & 0,000 & H0 ditolak & Terbukti \\
\hline
\end{tabular}


$\begin{array}{lll}\text { Keterangan: } & \text { X1 } & =\text { internal marketing } \\ \text { X2 } & =\text { Komitmen Organisasional } \\ \text { X3 } & =\text { Orientasi perusahaan } \\ \text { Y } & =\text { Kinerja } \\ & \text { T tabel }=1,974\end{array}$

Internal Marketing (X1) Berpengaruh Signifikan terhadap Kinerja Karyawan (Y)

Sebagaimana disajikan dalam Tabel 3 nilai $\mathrm{t}$ hitung untuk pengaruh variabel internal marketing (X1) terhadap Kinerja karyawan (Y) sebesar 3,122 dengan probabilitas menerima $\mathrm{H} 0$ dibawah alpha $(0,05)$ atau nilai t hitung telah melebihi batas kritis $\mathrm{t}$ tabel sebesar 1,974, dengan demikian nilai $\mathrm{t}$ hitung berada pada area tolak H0. Maka dapat disimpulkan bahwa hipotesis yang menyatakan bahwa "ada pengaruh internal marketing terhadap kinerja karyawan" dapat terbukti. Internal marketing terbukti mempengaruhi secara nyata terhadap kinerja karyawan CIMB Niaga Surabaya.

\section{Komitmen Organisasional (X2) Berpengaruh Signifikan terhadap Kinerja Karyawan (Y)}

Sebagaimana disajikan dalam Tabel 3 nilai t hitung untuk pengaruh variabel komitmen organisasional (X2) terhadap kinerja karyawan (X3) sebesar 4,477 dengan probabilitas menerima $\mathrm{H} 0$ dibawah alpha $(0,05)$ atau nilai $\mathrm{t}$ hitung telah melebihi batas kritis $\mathrm{t}$ tabel sebesar 1,974, dengan demikian nilai t hitung berada pada area tolak $\mathrm{H} 0$. Maka dapat disimpulkan bahwa hipotesis yang menyatakan bahwa "ada pengaruh komitmen organisional terhadap kinerja karyawan" dapat terbukti. Komitmen organisasional terbukti mempengaruhi secara nyata terhadap kinerja karyawan bank CIMB Niaga Surabaya.

\section{Orientasi Perusahaan (X3) Berpengaruh Signifikan terhadap Kinerja Karyawan} (Y)

Sebagaimana disajikan dalam Tabel 3 nilai $t$ hitung untuk pengaruh variabel Orientasi perusahaan (X3) terhadap kinerja karyawan (Y) sebesar 3,906 dengan probabilitas menerima $\mathrm{H} 0$ dibawah alpha $(0,05)$ atau nilai t hitung telah melebihi batas kritis $\mathrm{t}$ tabel sebesar 1,974, dengan demikian nilai t hitung berada pada area tolak $\mathrm{H} 0$. Maka dapat disimpulkan bahwa hipotesis yang menyatakan bahwa "ada pengaruh orientasi perusahaan terhadap kinerja karyawan" dapat terbukti. Orientasi perusahaan terbukti mempengaruhi secara nyata terhadap kinerja karyawan bank CIMB Niaga Surabaya.

\section{Internal Marketing (X1) Berpengaruh Signifikan terhadap Komitmen Organisasional (X2)}

Sebagaimana disajikan dalam Tabel 3 nilai $\mathrm{t}$ hitung untuk pengaruh variabel internal marketing (X1) terhadap komitmen organisasional (X2) sebesar 9,232 dengan probabilitas menerima $\mathrm{H} 0$ dibawah alpha $(0,05)$ atau nilai t hitung telah melebihi batas kritis $\mathrm{t}$ tabel sebesar 1,974, dengan demikian nilai t hitung berada pada area tolak $\mathrm{H} 0$. Maka dapat disimpulkan bahwa hipotesis yang menyatakan bahwa "ada pengaruh 
internal marketing terhadap komitmen organisasional" dapat terbukti. Internal marketing terbukti mempengaruhi secara nyata terhadap komitmen organisasional pegawai CIMB Niaga Surabaya.

\section{Internal Marketing (X1) Berpengaruh Signifikan terhadap Orientasi Perusahaan (X3)}

Sebagaimana disajikan dalam Tabel 3 nilai t hitung untuk pengaruh variabel internal marketing (X1) terhadap Orientasi perusahaan (X3) sebesar 5,220 dengan probabilitas menerima $\mathrm{H} 0$ dibawah alpha $(0,05)$ atau nilai $\mathrm{t}$ hitung telah melebihi batas kritis $\mathrm{t}$ tabel sebesar 1,974, dengan demikian nilai $\mathrm{t}$ hitung berada pada area tolak H0. Maka dapat disimpulkan bahwa hipotesis yang menyatakan bahwa "ada pengaruh internal marketing terhadap orientasi perusahaan" dapat terbukti. Internal marketing terbukti mempengaruhi secara nyata terhadap orientasi perusahaan CIMB Niaga Surabaya.

\section{Komitmen Organisasional (X2) Berpengaruh Signifikan terhadap Orientasi Perusahaan (X3)}

Sebagaimana disajikan dalam Tabel 3 nilai t hitung untuk pengaruh variabel komitmen organisasional (X2) terhadap Orientasi perusahaan (X3) sebesar 4,29 dengan probabilitas menerima $\mathrm{H} 0$ dibawah alpha $(0,05)$ atau nilai $\mathrm{t}$ hitung telah melebihi batas kritis $\mathrm{t}$ tabel sebesar 1,974, dengan demikian nilai $\mathrm{t}$ hitung berada pada area tolak H0. Maka dapat disimpulkan bahwa hipotesis yang menyatakan bahwa "ada pengaruh komitmen organisional terhadap orientasi perusahaan" dapat terbukti. Komitmen organisasional terbukti mempengaruhi secara nyata terhadap orientasi perusahaan CIMB Niaga Surabaya.

\section{Pembahasan}

Temuan penelitian ini telah membuktikan pengaruh nyata dari variabel internal marketing baik terhadap komitmen organisasional, orientasi perusahaan maupun terhadap kinerja. Analisis terhadap koefisien pengaruh dari fungsi model persamaan penelitian menunjukkan bahwa internal marketing mempunyai dampak positif terhadap peningkatan komitmen organisasional, orientasi perusahaan dan kinerja karyawan bank CIMB Niaga kantor cabang Surabaya.

Koefisien internal marketing sebagai prediktor tunggal terhadap komitmen organisasional memberikan kontribusi mencapai 33,3\%, dengan besaran koefisien model prediksi mencapai 0,693. Temuan ini memberikan bukti bahwa kebijakan internal marketing yang diberlakukan di perusahaan perbankan khususnya CIMBN Niaga memberikan kontribusi positif terhadap peningkatan komitmen pegawai terhadap institusi tempatnya bekerja. Sebagaimana diungkapkan oleh Meyer dan Allen (1991) komitmen merupakan keterikatan afektif, maupun bentuk kewajiban karyawan terhadap organisasinya, dalam hal ini komitmen organiasional berarti dimanifestasikan dalam bentuk kekuatan identifikasi dirinya dengan perusahaan. Kekuatan perasaan tersebut tentu timbul karena adanya kecocokkan diri pegawai dengan apa yang diterimanya dari organisasi. Zeithaml \& Bitner (2003:319) dalam roda penjabaran konsep internal marketing menyebut salah satu dari empat elemennya adalah 
mempertahankan pegawai terbaik (retain the best people)., yang diimplementasikan dalam bentuk kebijakan nyata terkait sumberdaya manusia, yaitu melakukan pengukuran dan memberikan penghargaan terhadap kinerja pelayanan terbaik (measure and reward strong service performance), memperlakukan karyawan sebagai pelanggan (treats employees as customers) dan memasukkan karyawan sebagai bagian dari visi perusahaan. Kebijakan-kebijakan sumberdaya manusia yang positif tersebut akan memberikan imbal balik berupa kerikatan yang kuat antara karyawan dan organisasi. Semakin baik internal marketing diterapkan di perusahaan maka komitmen karyawan pada perusahaan juga semakin tinggi.

Terhadap orientasi perusahaan, internal marketing juga kontribusi positif. Orientasi perusahaan ini dalam hal ini adalah orientasi terhadap pelanggannya. Semakin tinggi penerapan internal marketing maka akan diikuti dengan perubahan visi perusahaan terhadap pelanggan. Zeithaml \& Bitner (2003:319) dalam segitiga organisasi-karyawan-pelanggan, menunjukkan kaitan orientasi perusahaan dengan internal marketing. Hubungan perusahaan terhadap pelanggan merupakan bentuk external marketing dengan memberikan janji untuk memaksimalkan kepentingan dan pemenuhan kebutuhan pelanggan, sementara hubungan perusahaan (organisasi) dengan karyawan melalui internal marketing sebagai bentuk untuk mewujudkan janji external marketing. Zeithaml \& Bitner (2003:319) dalam roda penjabaran internal marketing menunjukkan bahwa tujuan inti dari internal marketing adalah penyampaian layanan yang berorientasi ke pelanggan (customer-orientedd service delivery). Temuan penelitian ini menunjukkan bahwa internal marketing terkait erat dengan orientasi perusahaan terkait dengan layanan kepada pelanggannya.

Internal marketing juga mempunyai peran penting terhadap kinerja baik langsung maupun tidak langsung. Temuan penelitian ini menunjukkan pengaruh langsung yang signifikan antara kebijakan internal marketing di bank CIMB Niaga Surabaya dengan kinerja karyawan. Sementara pengaruh tidak langsung menunjukkan dampak internal marketing terhadap kinerja melalui dampak mediasi, diantaranya adalahh melalui komitmen organisasional dan orientasi perusahaan. Shah (2014) dalam model service chain profit menggambarkan bahwa internal marketing mempunyai dampak tidak langsung terhadap kinerja. Begitu juga pada penelitian Vazifehdost dkk (2012) bahwa internal marketing mempunyai pengaruh langsung terhadap kinerja perusahaan. Zaman dkk (2012) juga menemukan hubungan yang signifikan antara implementasi internal marketing terhaddap kinerja sektor perbankan. Uraian diatas, memberikan gambaran bahwa temuan pada penelitian-penelitian sebelumnya selaras dengan teori dan penelitian saat ini.

Pada model persamaan kedua yang menganalisis pengaruh komitmen organisasional dan internal marketing terhadap orientasi perusahaan, menunjukkan pengaruh signifikan antara komitmen organisasional terhadap orientasi perusahaan. Temuan ini menunjukkan bahwa komitmen memediasi secara parsial internal marketing terhadap orientasi perusahaan. Sebagaimana dijelaskan oleh Zeithmal \& Bitner (2003:319) bahwa orientasi perusahaan terkait dengan cara pandang perusahaan terhadap kepentingan pelanggan, sementara karyawan merupakan elemen utama dalam menyampakan layanan hingga sampai ke pelanggan. Komitmen pegawai yang tinggi pada bank CIMB Niaga tempat dia bekerja, memungkinkan pegawai tersebut bekerja 
sesuai visi perusahaan, sebaliknya pada karyawan yang memiliki komitmen rendah, cenderung bekerja menurut kehendaknya.

Pada persamaan ketiga, di dapakan pengaruh signifikan dari komitmen organisasional dan orientasi perusahaan terhadap kinerja karyawan. Temuan ini memperjelas fungsi mediasi yang dimiliki komitmen organisasional maupun orientasi perusahaan pada pengaruh internal marketing terhadap kinerja karyawan. Temuan juga menunjukkan pengaruh langsung internal marketing terhadap kinerja karyawan yang menunjukkan bahwa bentuk mediasi yang ada pada komitmen organisasional maupun orientasi perusahaan bersifat parsial dan tidak menyeluruh. Ini berarti kebijakan internal marketing bisa langsung berakibat terhadap kinerja maupun melalui pengaruh tidak langung dengan memberikan dampak lebih dahulu terhadap peningkatan komitmen dan orientasi perusahaan. Temuan-temuan ini konsisten dengan temuan Vazifehdoost dkk (2012) yang menunjukkan bahwa komitment organisasional maupun orientasi perusahaan terhadap pelanggan memediasi internal marketing serta terbukti mempunyai pengaruh yang signifikan. Zaman dkk (2012) juga menunjukkan bukti pengaruh signifikan antara orientasi pasar dengan kinerja perbankan.

\section{KESIMPULAN DAN SARAN \\ Kesimpulan}

Berdasarkan hasil analisis dan pembahasan, maka dapat disimpulkan pokokpokok hasil penelitian, yaitu:

1. Penelitian ini menyimpulkan bahwa Internal marketing terbukti berpengaruh positif terhadap komitmen organisasional karyawan pada Bank CIMB Niaga Surabaya.

2. Temuan penelitian juga menyimpulkan bahwa Internal marketing berpengaruh terhadap orientasi perusahaan Bank CIMB Niaga Surabaya.

3. Penelitian ini menyimpulkan bahwa Internal marketing berpengaruh positif terhadap kinerja karyawan Bank CIMB Niaga Surabaya.

4. Temuan penelitian menunjukkan bahwa Komitmen organisasional berpengaruh terhadap orientasi perusahaan Bank CIMB Niaga Surabaya.

5. Penelitian ini juga menyimpulkan bahwa Komitmen organisasional berpengaruh terhadap kinerja karyawan Bank CIMB Niaga Surabaya.

6. Pengujian juga menyimpulkan bahwa Orientasi perusahaan berpengaruh terhadap kinerja karyawan Bank CIMB Niaga Surabaya.

\section{Saran}

Berdasarkan simpulan penelitian maka dapat diajukan saran-saran terkait penelitian ini, yaitu:

1. Bank CIMB Niaga Surabaya perlu mendorong dan meningkatkan kebijakan internal marketing guna mendorong peningkatan pelayanan perusahaan terhadap nasabah-nasabahnya. Upaya untuk meningkatkan dan memaksimalkan tersebut empat kebijakan pokok, memilih calon pegawai yang paling baik, mempertahankan pegawai yang mempunyai kinerja positif, mengembangkan sistem pendukung, dan mengembangkan pegawainya agar mampu menjalankan fungsi pelayanan secara maksimal. 
2. Untuk meningkatkan orientasi perusahaan terhadap pelanggan dapat mendorong kebijakan agar lebih mengutamakan nasabah, memperhatikan pesaing-pesaingnya, dan meningkatkan koordinasi antar fungsi di dalam perusahaan.

\section{DAFTAR PUSTAKA}

Abrori, H. 2015. Analisis perbandingan risiko kebangkrutan pada bank syariah devisa dan non devisa dengan menggunakan metode Altman Z-Score periode 20102012. UIN Walisongo.

Cahyoadi, B. 2016. Study Tentang Peningkatan Kinerja UKM melalui Pendekatan Faktor Inovasi Organisasi, Teknologi, Budaya Perusahaan dan Lingkungan Eksternal. Jurnal Pendidikan Ekonomi, 1(02).

Fatihudin, D., \& Firmansyah, A. 2019. Pemasaran Jasa:(Strategi, Mengukur Kepuasan Dan Loyalitas Pelanggan). Deepublish.

Fatonah, S., \& Awatara, I. G. P. D. 2019. Membangun Kinerja Pemasaran Berbasis Inovasi Produk dan Keunggulan Bersaing Kerajinan Batik. Journal of Indonesian Science Economic Research, 1(1), 45-49.

Ginting, E. V., \& Hati, S. W. 2020. Pengaruh Internal Marketing terhadap Organizational Performance di Erha Clinic dengan Market Orientation Sebagai Variabel Intervening. Jurnal Ilmiah Administrasi Bisnis Dan Inovasi, 4(1), 72 88.

Kuswandi, N., \& Mafazi, D. 2018. People Development Handbook (Vol. 2). Hasfa Publishing.

Mawei, R. 2016. Job Insecurity, Komitmen Organisasi Karyawan Dan Kepuasan Kerja Serta Dampaknya Terhadap Intention To Quit. Jurnal Riset Bisnis Dan Manajemen, 4(1), 17-32.

Meliangan, S., Tommy, P., \& Mekel, P. A. 2014. Analisis Perbandingan Kinerja Keuangan antara Bank BCA (Persero) Tbk dan Bank CIMB Niaga (Persero) Tbk. Jurnal EMBA: Jurnal Riset Ekonomi, Manajemen, Bisnis Dan Akuntansi, 2(3).

Muis, M. R., Jufrizen, J., \& Fahmi, M. 2018. Pengaruh Budaya Organisasi dan Komitmen Organisasi Terhadap Kinerja Karyawan. Jesya (Jurnal Ekonomi \& Ekonomi Syariah), 1(1), 9-25.

Muslim, R. B. 2019. Pengaruh Insentif, Komitmen Organisasi, dan Lingkungan Kerja Non Fisik Terhadap Kinerja Karyawan (Studi Kasus di PT. Artha Mas Abadi Pati). IAIN KUDUS.

Prastuti, W., \& Wikaningtyas, S. U. (2018). Pengaruh Kualitas Layanan Terhadap Kepuasan Pelanggan Pada Toko Sembako Koperasi Universitas Muhammadiyah Yogyakarta. STIE Widya Wiwaha.

Rangkuti, F. 2017. Customer Care Excellence: Meningkatkan Kinerja Perusahaan Melalui Pelayanan Prima Plus Analisis Kasus Jasa Raharja. Gramedia Pustaka Utama.

Toha, M. 2018. Analisis Pengaruh Profesionalisme, Kedisiplinan, Motivasi Kerja, Budaya Kerja dan Komunikasi Terhadap Kinerja Pegawai Otoritas Jasa Keuangan (Studi Kasus Kantor Regional 3 Jawa Tengah dan DIY). IAIN SALATIGA. 
Utomo, P., Arifin, S., \& Nuryadi, N. 2018. Kinerja Pelayanan Publik Pusat Kesehatan Masyarakat (Puskesmas) Sememi Surabaya. Jurnal Mitra Manajemen, 2(5), 406424.

Victory, V. 2014. Analisa Pengaruh Internal Marketing terhadap Organizational Performance dengan Rebranding dan Market Orientation sebagai Variabel Intervening pada Departemen Sales \& Marketing di Hotel Grand Aston Bali Beach Resort. Jurnal Strategi Pemasaran, 2(2), 1-10. 